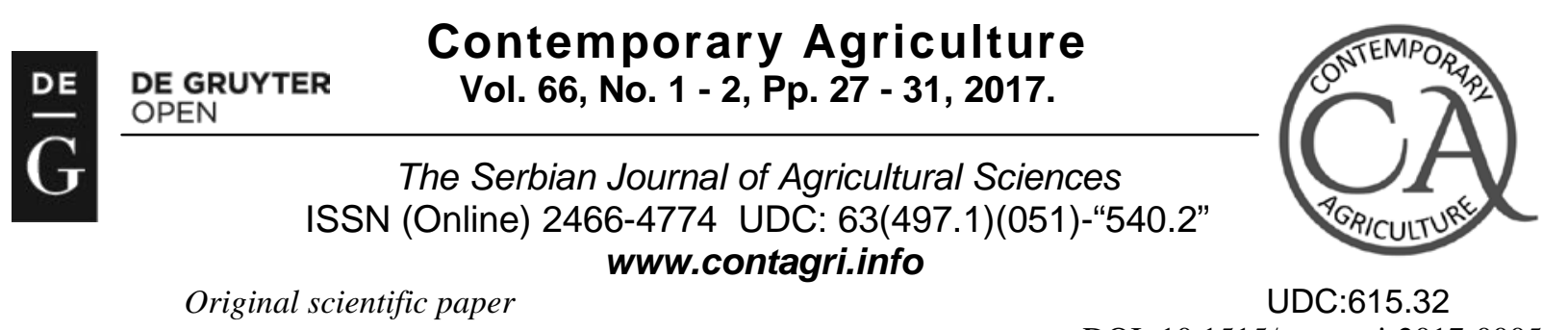

Original scientific paper

DOI: 10.1515/contagri-2017-0005

\title{
THE IMPORTANCE O FPLANTING POT MARIGOLDS (Calendula Officinalis L.) IN DEGRADED PUBLIC SPACES FROM THE AGROECOLOGICAL AND ECONOMIC PERSPECTIVE
}

\author{
Slobodan POPOVIĆ ${ }^{1}$, Slobodanka JOVIN ${ }^{2}$, Dragan ĐURANOVIĆ ${ }^{3}$, Vera POPOVIĆ \\ Vladimir FILIPOVIĆ ${ }^{5}$, Olja MUNITLAK-IVANOVIĆ ${ }^{6}$, Zeljko GRUBLJEŠIĆ ${ }^{7}$, Ranko MIJIĆ ${ }^{8}$
}

\begin{abstract}
Summary: The purpose of this paper is to analyse the introduction of certain plant species such as pot marigolds (Calendula officinalis L.) into neglected and predominantly urban spaces in the Republic of Serbia. The research was based on the results obtained in a two-year experiment conducted in the vicinity of the Novi Sad-Backa Palanka road. The primary objective of the experiment was to examine the behaviour of pot marigolds in poor-quality and neglected soils, with minimum cultural practices, in order to obtain novel plants in such adverse environments, which could be subsequently marketed in Serbia. The experiment commenced in 2014 by planting pot marigolds in plots previously cleared of weeds by mechanical tilling. In the spring of 2015, pot marigold seedlings, i.e. the first generation of plants obtained from the plots created in 2014, were planted in weed-free plots. The measurements were performed in three replicates from 10 October to 10 December 2015 in order to determine the number of volunteer plants, which could be further improved in nursery production and subsequently marketed in Serbia. The results obtained indubitably indicate that this and prospective studies exert positive ecological, agricultural and economic effects on a vast range of potential users.
\end{abstract}

Key words: neglected agricultural areas, volunteer plants, Calendula officinalis (L.).

\section{INTRODUCTION}

Nowadays, production management requires a sound and multidisciplinary approach (Popovic, 2014), encompassing socio-economic, ecological and agricultural considerations (Dinu, 2011; Hort et al., 2013; Mihaiescu, 2013; Bonaca and Dumitras, 2014; Popovic et al., 2014, Popovic, 2015). Contemporary agriculture should meet the criteria and demands of the economy. Therefore, it is of utmost importance to create a development paradigm for abandoned and uncultivated agricultural areas and degraded urban spaces in transition countries. This essentially entails the issue of spending the taxpayers' money by companies in charge with green space maintenance. There are many unused spaces of different size in every city, which ought to be reclaimed and repurposed for the benefit of the majority of residents.

New strategies are to be introduced (Simeunovic et al., 2012) in both domestic and international marketing (Gajdobranski, 2012, Marišovàet al., 2016). New approaches ought to place a greater emphasis on agriculture

\footnotetext{
${ }^{1}$ Slobodan Popović, Assistant Professor and Internal Auditor, JKP "Gradsko Zelenilo Novi Sad", Sutjeska 2, 21000 Novi Sad, Serbia,

${ }^{2}$ Slobodanka Jovin, Professor of applied studies, Business School of Novi Sad, 21000 Novi Sad, Serbia,

${ }^{3}$ Dragan Đuranović, Assistant Professor, Faculty of Economics, 24000 Subotica, Serbia,

${ }^{4}$ Vera Popović PhD, Institute of Field and Vegetable Crops, 21000 Novi Sad, Serbia,

${ }^{5}$ Vladimir Filipović, PhD, Institute for Medicinal Plants Research "Dr Josif Pančić”, 11000 Belgrade, Serbia,

${ }^{6}$ Olja Munitlak-Ivanović, Associated Professor, Institute of Economic Sciences, 11000 Belgrade, Serbia,

${ }^{7}$ Željko Grublješić PhD, Pension Fund, Office Of Prijedor, 79101 Prijedor, Bosna and Hercegovina,

${ }^{8}$ Ranko Mijić, Assistant Professor, College of Economics and Informatics Prijedor, 79000 Prijedor, Bosnia and Hercegovina

*Corresponding author: Slobodan Popović, e-mail: slobodan.popovic49@gmail.com, tel.: 0640483563.
} 
(Gritsenko and Skorba, 2015; Panchuk, 2015; Popovic et al., 2015), assessing business performance by means of financial reports, verification and audit (Majstorovic and Popovic, 2015). All the aforementioned should be viewed within the framework of sustainable development, and thus the authors draw particular attention to organic production (Radosavljevic et al., 2014).

Pot marigold (calendula officinalis L.) seedlings were planted in soil which has not been treated with herbicides or any other protection agents for at least 20 years. Volunteer plants obtained from the plot created in 2014 were used as a planting material. This research examined whether neglected areas could be used for the benefit of all citizens by planting cost-effective species and thereby reducing the allocations for urban green space maintenance. The paper makes recommendations on repurposing degraded urban spaces with minimum costs, cultural practices and irrigation, but without fertilisers. The idea was to plant pot marigolds in neglected and predominantly urban spaces and transplant them in nurseries (prior to reaching full maturity) for 15 to 30 days so that plants could be subsequently marketed and thus yield significant revenues.

\section{MATERIALS AND METHODS}

Green space maintenance in the city involves, among other things, the maintenance of abandoned and neglected urban areas. On balance, such areas have not been cultivated for several decades nor used for any kind of production, and the objective of a potential repurposing would be to create environmentally-friendly urban oases. The two-year experiment in this paper was conducted in the period 2014-15 on weedy plots, which had not been used for more than 20 years. The plots were cleared of weeds manually and by mechanical tilling performed on two occasions. Upon land fragmentation and pot marigold planting, the results obtained at the end of the vegetative growth period are presented via the number of volunteer plants per $\mathrm{m}^{2}$.

The experiment commenced in 2014 by planting a certain number of pot marigolds (Calendula officinalis L.), in previously prepared and weed-free soil, to obtain a sufficient number of healthy volunteer plants, which would be used as a planting material the following year. In 2015, pot marigolds were planted (10 per $1 \mathrm{~m}^{2}$ ) in 10 mechanically cleared plots, which were in the immediate vicinity of 10 control plots. To prevent extreme heat exposure, watering was performed on 6 occasions with 50\% less water than used for the irrigation and maintenance of green spaces in the city.

The objective was to determine the real potential of volunteer plants and long-neglected areas, which could be repurposed in an ecologically and economically beneficial manner. In addition to the number of volunteer plants (emerging from 10 October to 10 December in 2015), particular attention was paid to plants which could be refined in a nursery in a short time and marketed in the Republic of Serbia at the average market price.

\section{RESULTS}

The experiment was conducted under field conditions in mechanically cleared long-neglected plots (more than 20 years), which were in the immediate vicinity of the highly - frequented Novi Sad - Backa Palanka road. The plots were of a $1 \times 1 \mathrm{~m}^{2}$ size with adjacent control plots of the same size. Table 1 shows the number of volunteer plants in the experimental and control plots recorded during a three-day measurement in a three-month period of observation.

Table 1. The number of volunteer plants in the trail and control plots

\begin{tabular}{|c|c|c|c|c|c|c|}
\hline \multirow{3}{*}{ Plot } & \multicolumn{6}{|c|}{ Results of daily measurements } \\
\cline { 2 - 7 } & \multicolumn{2}{|c|}{10.10 .2015} & \multicolumn{2}{c|}{$\mathbf{1 0 . 1 1 . 2 0 1 5}$} & \multicolumn{2}{c|}{$\mathbf{1 0 . 1 2 . 2 0 1 5}$} \\
\cline { 2 - 7 } & $\mathrm{A}$ & $\mathrm{B}$ & $\mathrm{A}$ & $\mathrm{B}$ & $\mathrm{A}$ & $\mathrm{B}$ \\
\hline & 60 & 57 & 70 & 71 & 40 & 35 \\
\hline 2 & 59 & 61 & 71 & 72 & 38 & 37 \\
\hline 3 & 54 & 58 & 73 & 74 & 40 & 39 \\
\hline 4 & 59 & 50 & 74 & 75 & 39 & 40 \\
\hline 5 & 58 & 59 & 78 & 78 & 40 & 41 \\
\hline 6 & 60 & 60 & 78 & 77 & 40 & 40 \\
\hline 7 & 60 & 64 & 75 & 74 & 39 & 39 \\
\hline 8 & 59 & 62 & 72 & 75 & 39 & 41 \\
\hline 9 & 60 & 61 & 70 & 74 & 38 & 41 \\
\hline 10 & 59 & 61 & 69 & 72 & 39 & 40 \\
\hline
\end{tabular}


Note $\left(\mathrm{A}=\right.$ an experimental area of $1 \mathrm{~m}^{2}, \mathrm{~B}=$ a control area of $\left.1 \mathrm{~m}^{2}\right)$

The one-way analysis of variance (ANOVA) was usedto examine whether there were statistically significant differences in the number of volunteer plants measured in the experimental (A) and control (B) plots. The ANOVA results are displayed in Table 2.

Table 2. Statistical differences in the measurement results between the experimental and control groups

\begin{tabular}{|c|c|c|c|c|c|}
\hline & Sum of Squares & Df & Mean Square & F & Sig. \\
\hline $\begin{array}{c}\text { Between } \\
\text { Groups }\end{array}$ & 5760.800 & 2 & 2880.400 & 601.941 & .000 \\
\hline Within Groups & 129.200 & 27 & 4.785 & & \\
\hline Total & 5890.000 & 29 & & & 394.666 \\
\hline $\begin{array}{c}\text { Between } \\
\text { Groups }\end{array}$ & 6133.400 & 2 & 3066.700 & & .000 \\
\hline Within Groups & 209.800 & 27 & 29 & & \\
\hline Total & 6343.200 & 29 & & & \\
\hline
\end{tabular}

The results shown in Table 2 indicate that there are statistically significant differences between the values obtained for the experimental plot/group A $(\mathrm{F}(2.27)=601.94, \mathrm{p} \leq .001)$ and the control plot/group B $(\mathrm{F}(2.27)=$ 394.67, $\mathrm{p} \leq .001$ ). Further statistical analysis of the data obtained involved using the post-hoc and the Scheffe's test (Table 3).

Table 3. The results of the post hoc and the Scheffe's test

\begin{tabular}{|c|c|c|c|c|c|}
\hline $\begin{array}{l}\text { Dependent } \\
\text { Variable }\end{array}$ & (I) Month & (J) Month & $\begin{array}{c}\text { Mean Difference } \\
\text { (I-J) }\end{array}$ & Std. Error & Sig. \\
\hline \multirow{6}{*}{ A } & \multirow[t]{2}{*}{ Oct. } & Nov. & $-14.20000^{*}$ & .97828 & .000 \\
\hline & & Dec. & $19.60000^{*}$ & .97828 & .000 \\
\hline & \multirow[t]{2}{*}{ Nov. } & Oct. & $14.20000^{*}$ & .97828 & .000 \\
\hline & & Dec. & $33.80000^{*}$ & .97828 & .000 \\
\hline & \multirow[t]{2}{*}{ Dec. } & Oct. & $-19.60000^{*}$ & .97828 & .000 \\
\hline & & Nov. & $-33.80000^{*}$ & .97828 & .000 \\
\hline \multirow{6}{*}{ B } & \multirow[t]{2}{*}{ Oct. } & Nov. & $-14.90000^{*}$ & 1.24663 & .000 \\
\hline & & Dec. & $20.00000^{*}$ & 1.24663 & .000 \\
\hline & \multirow[t]{2}{*}{ Nov. } & Oct. & $14.90000^{*}$ & 1.24663 & .000 \\
\hline & & Dec. & $34.90000^{*}$ & 1.24663 & .000 \\
\hline & \multirow[t]{2}{*}{ Dec. } & Oct. & $-20.00000^{*}$ & 1.24663 & .000 \\
\hline & & Nov. & $-34.90000^{*}$ & 1.24663 & .000 \\
\hline
\end{tabular}

It is clearly discernible from Table 3 that there are significant statistical differences in the measurement results obtained for the experimental plot A. The average value in October is significantly lower compared to the November value, but also significantly higher compared to the December value. Furthermore, the rates measured in November are significantly higher than those measured in December.

There are also significant statistical differences in the measurement results obtained for the control plot B. The average value in October is significantly lower compared to the November value, but significantly higher than the December value, whereas the November value is significantly higher compared to the December value. 
A t-test was used to determine significant statistical differences between the A and B measurement values. The results show that there is no significant statistical difference $(t(29)=-1.212, p \geq 0.05)$ and that both $A$ and $B$ values are equal.

\section{DISCUSSION}

This paper draws attention to the importance of a professional and multidisciplinary approach in addressing the issues of degraded and abandoned urban areas in large Serbian towns. Such issues have been present for a number of decades, and significant improvements are required for the economic benefits of all city dwellers, especially regarding the application of cultural practices and environment-friendly growing technologies. Therefore, the introduction of certain plants into degraded and abandoned urban areas can have positive financial effects on municipal budgets, which was confirmed in this study.

Table 4 illustrates the expected number of volunteer plants per unit area, which could be further upgraded in nursery production, and the value of volunteer plants obtained according to the average selling price (RSD) in Serbia at the end of 2015 .

Table 4. A tabular representation of the estimated results regarding the number of volunteer plants and their value according to the average selling price (RSD) in Serbia at the end of 2015

\begin{tabular}{|c|c|c|}
\hline Agricultural land & $\begin{array}{c}\text { Number of volunteers that can be } \\
\text { further upgraded in nursery } \\
\text { production }\end{array}$ & $\begin{array}{c}\text { Estimated value in RSD based on the number of } \\
\text { plants per unit area }\end{array}$ \\
\hline $1 \mathrm{ha}$ & 57,300 & $1,564,290$ \\
\hline $10 \mathrm{ha}$ & 573,000 & $15,642,900$ \\
\hline
\end{tabular}

The estimated values clearly indicate that it is possible to obtain weed-free agricultural land from degraded and neglected areas with minimum mechanical and cultural practices. Moreover, novel plants created in such manner could be used as planting materials or marketed as cash crops. A great number of volunteer plants would emerge spontaneously per 1 hectare of cleared land, which entirely justifies the planting of certain species in abandoned and neglected areas.

It is noteworthy that local government allocate funds for weed control, and that such costs could be covered by selling plants grown in plots cleared of weeds. Furthermore, every large town in the Republic of Serbia features dozens and hundreds of hectares of rough and degraded areas, which require regular maintenance and weed control. Introducing valuable plants even into a small part of such spaces would yield revenues, facilitating further investments in the argy-environmental programs of local communities.

\section{CONCLUSION}

Green space maintenance in urban areas requires considerable expenditure. Transition countries such as Serbia feature vast spaces which are weedy and unused for decades. The purpose of this paper was to demonstrate that the introduction of certain plant species such as pot marigolds (calendula officinalis L.) into neglected and predominantly urban areas would be beneficial for both city dwellers and the environment. The results obtained in a two-year experiment were used in the research.

The average number of pot marigold volunteer plants, which could be further improved in nurseries for marketing, easily amounted to 40 per $\mathrm{m}^{2}$ in December and 70 per $\mathrm{m}^{2}$ in November. The estimated financial effects amply justify and clearly indicate the great potential of introducing valuable plants in neglected and abandoned urban areas. Moreover, significant statistical differences were recorded in the experimental and control plots $(\mathrm{t}(29)=-$ $1.212, \mathrm{p} \geq 0.05$ ), and it can be argued that the values measured in both plots are equal.

\section{REFERENCES}

BONACA, I. AND DUMITRAS, L.: Integrated System in Landscaping Design and Landscape Ecology: Simplicity or Complexity?, ProEnvironment, 7: 46-52, 2014.

DINU, V.: Corporate Social Responsibility-Opportunity for Reconciliation between Economical Interests and Social and Environmental Interests, Amfiteatru Economic, 29: 6-7. 2011.

GAJDOBRANSKI, A.: Uticaj spoljne trgovine (izvoza - uvoza) na proizvodnju na primeru nekih poljoprivrednih proizvoda, Agroekonomika, 56:89-98, 2012. 
GRITSENKO, O.I. AND SKROBA, O.A.: Internal business control of service quality costs: managerial aspect, Actual problems of economics, No. 3 (165): 365-373, 2015.

HORT, D., CANTOR, M., BUTA E., HUSTI, A.: Control of Soil Erosion on Slopes by Using Dendrological Species, ProEnvironment, 6: 499-502, 2013.

MARIŠOVÀ, E., MILOVANOVIĆ, J., ĐORĐEVIĆ, S., JEREKOVÀ, Z., DRAŽIĆ, G., HAUPTVOGL, M., PRČIK, M, MARIŠ, M., KORTLA, M., FANDEL, P., ILKOVA, Z., GADUŠ, J., POPOVIĆ, V., IKANOVIĆ, J., ŽIVANOVIĆ, LJ, RADOJEVIĆ, U., KOVÀČIK M. AND MANDALOVÀ K.: Agro-energy for sustainable agriculture and rural development. Good practices from Slovakia-Serbia bilateral cooperation. Belgrade. Monograph. CD Rom Copy, 300. 1-291., 2016.

MAJSTOROVIĆ, A. AND POPOVIĆ, S.: Revizija poslovanja poljoprivrednog preduzeća, Računovodstvo, 1, 77-85, 2015.

Mihaiescu, T.: Assessment of Soil Erosion Risk in Fizes River Catchment Using USLE Model and GIS, ProEnvironment 6: 595599, 2013.

PANCHUK, I.P.: Harmonization of accounting and taxation accounting at reporting formation on income, Actual problems of economics, No. 3 (165): 373-379, 2015.

POPOVIC, S.: Socio - ekonomski faktori ograničenja razvoja agrara, Feljton, Novi Sad, pp. 30, 2014.

POPOVIC M.V.: Pojam, podela i značaj bioloških resursa u poljoprivredi. Ured. Milovanovic Je., Đorđević S.: Očuvanje i unapređenje bioloških resursa u službi ekoremedijacije. Monografija. Beograd, ISBN 978-86-86859-41-9; 1-407.29 - 51. 2015.

POPOVIC, S., TOŠKOVIĆ J., GRUBLJEŠIĆ, Ž.: Environmental-Economic Model of Developing Composters in Parks, Protected Areas and City Limits in the Republic of Serbia, ProEnvironment, 7: 213-217, 2014-b.

POPOVIC, S., MAJSTOROVIĆ, A., GRUBLJEŠIĆ, Ž.: Valuation of facilities in use and application of international accounting standards, Actual problems of economics, 3:165, 379-387, 2015.

RADOSAVLJEVIC, Ž, GAJDOBRANSKI, A., KRMPOT, V.: Održivi razvoj iorganska proizvodnja kao bitni faktori savremene poljoprivredne proizvodnje, Agroekonomika, 61-62:20-30, 2014.

SIMEUNOVIC, T., LUGONJA, D., SIMEUNOVIĆ J.: Strategija nastupa i promene organizacione structure preduzeća u međunarodnom poslovanju, Agroekonomika, 56:79-88, 2012.

\section{ZNAČAJ SADNJE BILJKA NA DEGRADIRANIM JAVNIM POVRŠINAMA SA AGRO-EKOLOŠKOG I EKONOMSKOG ASPEKTA NA PRIMERU BILJKE NEVEN (CALENDULA OFFICINALIS L.)}

Izvod: U ovomradu autori analiziraju uvođenje sadnje pojedinih biljnih vrsta, na primeru biljke nevena (Calendula officinalis L.) i to na zapuštenim površinama, pretežno gradskim parcelama u Republici Srbiji. Za izradu ovog rada korišteni su dvogodišnji eksperimentalni rezultati koji su dobijeni na prostoru oboda Grada Novog Sada, u neposrednoj blizini saobraćajnice na putu Novi Sad-Bačka Palanka. Prvenstveni interes autora je bio da se eksperimentalno ispita ponašanje pomenute biljne vrste, koja je sađena u lošim i zapuštenim zemljištima, uz minimalnu mehaničku pripremu zemljišta, sa ciljem dobijanja novih biljaka koje nastaju na takvom prostoru, a koje se mogu dalje prodati na tržištu, pre svega Republike Srbije. Eksperiment je počeot tokom 2014., nabavkom biljaka koje su posađene na zemljištu koje je prethodno mehanički očišćeno od korovskih biljaka, da bi bio nastavljen tokom 2015. Početkom proleća naprethodno očišćenom zemljištu od korova posađene su mlade biljke nevena (Calendula officinalis L.), koje su u suštini prva generacija prethodno sađenih biljaka. Rezultati merenja su vršeni u tri navrata i to u intervalu od 10.10. do 10.12.2015., sa ciljem utvrđivanja broja samoniklih biljaka koje se mogu dalje doraditi u rasadničkoj proizvodnji. Cilj ovakve dorade bi bio prodaja, pre svega natržištu Republike Srbije. Dobijeni rezultati jasno ukazuju, da ova i slična ispitivanja imaju ekološko-agrarni i ekonomski značaj. Krajnji efekti su pozitivni i ispoljavaju svoje delovanje na širi krug mogućih korisnika.

Ključne reči: zapuštene poljoprivredne površine, samonikle biljke, Calendula officinalis (L.).

Received / Primljen: 26.12.2017. Accepted / Prihvaćen: 04.07.2017. 